\title{
The Holocaust, Apartheid, and Contemporary South African Jewish Perspectives on Victimhood
}

\section{Shirli Gilbert and Deborah Posel}

\section{$\underline{\text { Abstract }}$}

Drawing on interviews with South Africans who identify as Jewish but situate themselves outside what they regard as the communal mainstream, this article focuses on the extent to which their Jewishness is impacted by memory of the Holocaust. Across the age spectrum, respondents criticized what they perceived to be a dominant preoccupation with Jewish victimhood, which they saw being used to defend problematic political and social views. They rejected not the reality of historic Jewish victimhood but rather the idea that victimhood stands at the centre of Jewish identity. The Holocaust significantly informed their thinking on a range of issues, notably a commitment to social justice, but they were careful to differentiate their positions from what they considered to be the Jewish mainstream, whose narratives were seen to focus instead on Jewish preservation and self-defence. Their views echo the diverging Holocaust memory cultures that developed between activist Jews and communal institutions during the apartheid years.

\section{$\underline{\text { Introduction }}$}

This article stems from a larger study that explores aspects of contemporary South African Jewish identity, focusing on individuals who identify as Jewish but situate themselves outside what they consider to be the communal mainstream. The term 'progressive Jews' is used to refer to them collectively, although they represent a broad political spectrum ranging from liberal through to social democrat and Marxist/socialist. All endorse principles of social justice, and many seek alternative Jewish institutions that they feel resonate better with their 
values. Alongside archival research, in-depth interviews were conducted with 55 South African Jews of varying ages. ${ }^{1}$ Our central aim was to understand how they define and practice their Jewishness in the distinctive historical and political context of contemporary post-apartheid South Africa.

The article focuses on one of the key questions that was explored during these interviews, namely the extent to which memory of the Holocaust has inflected our respondents' self-understanding as Jews and their engagement with South African society. The latter is an issue that is complicated by the pervasiveness of Israel-apartheid analogies, particularly in the governmental and media realms, as well as a state-sanctioned discourse about the apartheid past that is infused with references to the Holocaust.

Memory of the Holocaust significantly informs how many of our respondents understand and define their Jewishness, but it does so in complex and sometimes paradoxical ways. This is in large part because of how they associate the subject with organised Jewry, with whom they have an uneasy relationship. Many respondents felt that these circles were excessively preoccupied with Jewish victimhood, a narrative they saw underpinned especially by memory of the Holocaust, and which was being used to justify what they considered problematic attitudes on a range of social and political issues, particularly South African racial issues and the Israeli-Palestinian conflict. It was not the fact of historic Jewish victimhood that they were rejecting — many expressed a deep connection to the Jewish past and a concern for the Jewish future - but rather the idea that victimhood stood at the centre of Jewish life and identity. Some explicitly claimed that the Holocaust was not central to their Jewish identities, while others spoke more broadly of rejecting a victim-centred outlook. In many of the interviews, however, it was clear that the history of antisemitism and the Holocaust had influenced their Jewishness to a greater or lesser degree, though often in diverging ways from what they considered to be the communal mainstream. 
In the first part of the article we provide a brief account of the historical origins of South African Jewry as well as the trajectory of Holocaust memorialisation in South Africa, in order to situate the perspectives of our respondents. In the second part of the article we outline our research findings.

\section{$\underline{\text { Background and context }}$}

Following the first Jewish settlers in South Africa, who arrived in the mid-19th century primarily from Britain, Holland, and Germany, the largest influx of immigrants came from Lithuania at the turn of the twentieth century. At its peak in the 1970s the Jewish population numbered around 120,000; at the time of writing it is estimated at around 50,000, as substantial numbers have emigrated..$^{2}$

Jews' efforts to gain acceptance in the South African racial order depended from the outset on their being recognized as white. These efforts began early in the twentieth century, as the premium attached to ideas of racial difference rapidly increased. After the creation of the Union of South Africa in 1910, the pursuit of a system of white supremacy picked up momentum, as legislation accumulated to assign access to opportunities, wealth and privilege on racial lines. The norms and values of racial segregationism became hegemonic, as everyday life in South Africa was dominated by notions of a supposedly natural hierarchy of racial worth that positioned white people unassailably at the top. For Jews, it would have been clear that prospects for educational and commercial success, upward mobility, and political acceptance would depend on their racial status. Their pursuit of social mobility was also linked to their long history of persecution in Europe, a paradoxical relationship that fundamentally shaped South African Jewry's identity and self-definition.

Recognition of Jews' 'whiteness' was not immediately or straightforwardly won, however. During the late $19^{\text {th }}$ and early $20^{\text {th }}$ centuries anti-Jewish sentiment was widespread 
in South Africa, targeting Jews for their poverty as well as their economic success (a trend echoed across the Diaspora). In the 1930s and 40s, antisemitism became increasingly political, influenced in part by the rise of Nazism. In 1930, the newly-passed Quota Act targeted Jewish immigration to South Africa from Lithuania, and the idea of Jewish 'unassimilability', which questioned the very possibility of Jewish integration into society, was becoming popular in Afrikaner nationalist circles. By the late 1930s, in addition to the growth of several far-right antisemitic movements, antisemitism had become an integral part of the mainstream National Party's platform. At this time, only around half of Jews living in South Africa were native-born. In the immediate postwar years, memory of the Nazi genocide coupled with Nazi-inspired Afrikaner antisemitism engendered for these Jews a profound sense of isolation and vulnerability. ${ }^{3}$

From early on, South African Jewry's historical victimhood was inseparable from its Zionism. The prospective Jewish homeland, a refuge for Jews under threat, was felt crucially necessary given experiences of antisemitism abroad and at home. South African Jews have long been recognized as among the most ardently Zionist in the Diaspora, although views have spanned the ideological spectrum. After the advent of apartheid in 1948, the same year in which Israel was established, Zionism became a focal point of institutional communal life, strongly connected with the powerful memory of recent Jewish persecution. In the succeeding years, Zionism and the Holocaust took root as the central pillars of South African Jewry's identity and sense of community. ${ }^{4}$

A word of introduction is necessary about the distinctive nature of community and communal leadership among South African Jewry. Unlike other Diaspora communities, in South Africa a great deal of emphasis has historically been placed on communal unity, a point frequently celebrated by outside observers. A highly centralized communal structure, made up of national institutions including the South African Jewish Board of Deputies (on 
the British model), the South African Zionist Federation and the South African Jewish Board of Education has long overseen the greater part of communal life and activity. There is a well-developed network of Jewish schools, synagogue affiliation is widespread, and support for Zionism is strong. ${ }^{5}$ Jews in South Africa have nonetheless remained somewhat heterogeneous, not least in their national political positions, even if the margins - while prominent and influential—were relatively small. In referring to 'mainstream' Jewry in this article, we refer to these communal structures as well as the expectations and values they endorse, while recognizing that individuals who comprise the community doubtless represent greater diversity. Many Jews have found this communal cohesiveness valuable and reassuring in a context of continued social instability and political uncertainty, though for some, including many of our respondents, it has resulted in growing insularity and intolerance of dissent. $^{6}$

Apartheid divided South African Jews. On the one hand, Jews continued to be overrepresented in leftist political resistance to white supremacy, as they had been since the early 1900 s. These Jews represented only a small fraction of the community, however, and in many cases they were unaffiliated with, or ostracized from, the mainstream. On the other hand, the majority of Jews accommodated themselves to the principle of white supremacy. Though they tended not to support the governing National Party and were critical of some of its excesses, on the whole they lived within the apartheid system without fundamentally challenging it. Ironically, it was apartheid, and the totalising racial order it entailed, that cemented their status as white.

One source of division among Jews was diverging attitudes to Jewish victimhood. The Holocaust in particular served as powerful currency in internal debates about how to respond to apartheid, but distinct memory cultures developed alongside differing political stances. For the minority, memory of Jewish persecution spurred a powerful commitment to anti-racism 
and social justice. There are many examples of Jewish activists, liberals, intellectuals, and rabbis who explicitly reproached the organised community for its failure to heed the 'lessons' of Jewish history and oppose racial injustice. ${ }^{7}$ (It should be noted, however, that some denied any Jewish motivations for their activism, embracing instead a universal humanism more aligned with anti-apartheid discourse) ${ }^{8}$

In the discourse of mainstream Jewish institutions, by contrast, the Holocaust was, and remains, a marker of Jews' enduring vulnerability in the modern world. By as early as 1960, South African Jews had established more memorials and commemorative activities than most other communities in the Diaspora. ${ }^{9}$ Throughout the apartheid period, Holocaust remembrance and education focused on internal Jewish concerns about self-preservation and defence, with little or no reference to the local context. Much focus was placed on the young fighters of the Warsaw Ghetto Uprising, unambiguously connected with the reborn 'new Jew' of Israel who relied on his own strength and defences in preserving the Jewish future. Communal leaders warned repeatedly of the antisemitic dangers that Jews faced in the postNazi era, and emphasized that the obvious lesson to be learned from the Holocaust was that only self-reliance, particularly in the form of Israel, could ensure Jewish existence. ${ }^{10}$

Despite earlier Afrikaner antisemitism, Jews' experiences of antisemitism after 1948 seem to have been limited. Until the 1990s, successive surveys emphasized Jews' successful acculturation in South Africa, their rapid upward economic mobility, and their high levels of education and professional success; the issue of antisemitism hardly featured. ${ }^{11}$ Annual reports produced for the American Jewish Year Book (AJYB), which summarized demographic, political, educational and other developments, suggest that while antisemitism was not absent from South African life during the apartheid period, it was never widespread. Until the 1980s, antisemitic agitation came chiefly from far-right fringe groups and individuals, some of whom had links with neo-Nazis abroad. ${ }^{12}$ Despite isolated incidents of 
public controversy around Jews, including in parliament, the National Party government consistently repudiated antisemitism, a point often emphasized by the South African Jewish Board of Deputies. ${ }^{13}$ From the late 1970s, Holocaust denial was evident, particularly in the form of the openly Nazi-inspired Afrikaner Weerstandsbeweging (Afrikaans Resistance Organisation, AWB), although according to the historian Milton Shain, it never approximated the levels it did in Europe. ${ }^{14}$ The 1998 National Survey of South African Jews found that 'antisemitism largely falls within the realm of unpleasant discourse in South Africa and is of minor importance in political terms,' and reported that over a third of the sample surveyed had had no personal experience of antisemitism in five years. ${ }^{15}$ By 2005 , those numbers had decreased even further. ${ }^{16}$

Anti-Zionism, however, notably increased in the early 2000s, and remains the most concerning issue for South African Jews today. ${ }^{17}$ The ruling African National Congress (ANC) has not taken any actions to prejudice or disadvantage Jews within the country. But perhaps unsurprisingly, given its historical relationship with the Palestinian liberation struggle, the ANC has consistently expressed its opposition to Israeli government policy, and its elected officials echo the widespread comparison between Israel and apartheid. The mainstream media does likewise. The Jewish communal authorities express deep concern about these views, which they perceive to be not only one-sided but also antisemitic. ${ }^{18}$

Anti-Zionist attitudes exist in the contemporary South African public sphere alongside a highly universalized narrative of Holocaust remembrance, which entered mainstream discourse during the political transition of the 1990s. The Holocaust was frequently invoked as a benchmark for thinking about South Africa's recent past, from the debate about the future of Robben Island to the conception of the Truth and Reconciliation Commission. It also became a means for mainstream Jewry to assert its commitment to the new South Africa, in forums such as the 'Anne Frank in the World' exhibition (1994) and the Cape Town 
Holocaust Centre (est. 1999). In present-day South Africa, Holocaust memory is firmly embedded in a universal discourse of human rights, anti-racism and social justice, although Jewish institutions retain a strong internal focus on the event's uniqueness and links with Israel. ${ }^{19}$

\section{$\underline{\text { Research findings }}$}

Across our interviews, the Holocaust clearly informed respondents' thinking on a number of issues, including their senses of themselves and their role in the world as Jews. Their uncomfortable relationship with the Jewish mainstream, however, coloured the way in which the impact of the Holocaust was understood and articulated. Our respondents seemed to be reacting in particular to what they saw as the dominant preoccupation with Jewish victimhood, a position they felt was being used to defend problematic political and social views.

A striking disjuncture emerged in the interviews regarding the event's centrality to our respondents' Jewish identities. Fourteen took pains to emphasize that the Holocaust was not central to their identity as Jews, while only four explicitly claimed that the Holocaust was central. To a small degree, this is perhaps an historical legacy: few refugees and survivors found their way to South Africa in the 1930s and 40s because of immigration restrictions, and the geographic distance meant that events in Europe were inevitably experienced at something of a remove. In the personal and family experience of some South African Jews, the Holocaust simply does not loom large.

There are more significant underlying issues, however. Fundamental to the disjuncture evident in our interviews was the discomfort that many of our respondents felt with regard to the Jewish mainstream. Echoing the political and ideological divisions of the apartheid years, these respondents linked Holocaust memory with a commitment to anti- 
racism and social justice, rejecting dominant communal narratives that linked the Holocaust primarily with Jewish preservation and the need for a strong Israel. There were further generational inflections to how these views were articulated. While many respondents across the age spectrum described their discomfort with the institutional mainstream, referring to what they considered to be its narrow-mindedness on a range of social and political issuesin particular, its largely unquestioning support of the Israeli government, its attitudes towards gender and sexuality, and its perceived racism—older generations still felt a sense of Jewish vulnerability, and were accordingly more nuanced in their criticism. Younger generations were less guarded in their criticism and less sympathetic to narratives of enduring Jewish victimhood, which they saw being used to justify an insular and intolerant worldview.

As many as twenty of our respondents - more than a third, primarily but not exclusively under the age of 50-expressed discomfort with what they perceived to be a dominant victim-centred identity. Paul, in his 20s, articulated his perspective as follows:

You're fed into this conversation that's going around and circulating, almost subconsciously, that we're still persecuted and that we're sort of just waiting for the next devastating catastrophe. And that is a really strong glue for the community, I think. But it also has really damaging consequences. And it leads to quite a strange sort of mentality when it comes to viewing everyone else. [...] All the paranoia gets absorbed into the single concept called the Holocaust [...]. I think one of the difficult things has been trying to define how I identify myself as Jewish outside of the parameter of paranoia. [...] I don't want to define my allegiance to Judaism because of a sense of shared suffering, even though I know that so often that's the basis for so many identities. Because I don't feel like I've suffered, ever. ${ }^{20}$ 
A few distinct themes emerge from these comments. First is the question of South African Jews' personal experiences of antisemitism. Paul contends that although antisemitism is not really in evidence in South Africa, Jewish institutions and leaders continue to promote a narrative of enduring victimhood in order to encourage communal unity and cohesiveness. Memory of the Holocaust seems to underpin their 'paranoia'. This focus on victimhood prompts several further concerns: it adversely affects how Jews relate to 'everyone else', and results in a Jewish identity defined in negative rather than positive terms.

The vast majority of our respondents in their 20s and 30s echoed Paul's sentiments, asserting that they had never experienced antisemitism directly in South Africa and did not feel threatened by it. Dylan, for example, noted that 'I don't think South Africa, especially for young people, is an antisemitic country. I think there's far more antisemitism overseas. ${ }^{21} \mathrm{~A}$ few young people had experienced incidents on university campuses, in the form of offensive comments or, in one case, swastikas on a Jewish candidate's election posters. The increase in such campus incidents (others have been reported in the local press and anecdotally) seems to be related to increased anti-Israel activism at South African universities, a phenomenon that reinforces fears about hostile public discourse. Younger respondents, however, considered these fears 'overblown or over-spoken-of' ${ }^{22}$ On the whole, they agreed with Paul's sense that 'I don't feel like I've suffered, ever.' One of the key reasons they emphasized the absence of antisemitism was to explain why the dominant preoccupation with victimhood feels 'paranoid'.

While some older respondents also refused the centrality of victimhood to their Jewish identities, for them the threat of antisemitism was not as easily dismissed. To begin with, the significant discrimination experienced by earlier generations of Jewish South Africans, particularly in the first half of the twentieth century, was more prominent in their consciousness. Judy, in her 50s, remembered her grandfather's persistent fears: 
My zayde's generation - so we're talking the generation that came from Lithuania strongly identified with their Jewishness and were very fearful that there would be a rise of antisemitism in the country. And they kept their heads down. They felt that at any minute, the moment could turn and antisemitism could raise its ugly head again. I remember when Verwoerd died [in 1966], I was six. And I remember my zayde saying that he hoped it wasn't a Jewish person that assassinated Verwoerd [...]. Because they were so scared that it would raise antisemitism in the country. And there was that moment in the 30 s when there was that really antisemitic moment in government. So they always lived with that fear. He did. ${ }^{23}$

Renée, in her 90s, recalled her father being refused a job at a bank because he was Jewish. She also recounted several antisemitic incidents from her own school years in the 1930s and 40s, and said that she had always felt a persistent sense of otherness as a Jew in South Africa. ${ }^{24}$ For Jews who came of age in this period, the concrete threat of Afrikaner antisemitism, against the backdrop of Nazi persecution in Europe, translated into a direct and enduring anxiety about Jewish vulnerability.

Some of our respondents who grew up in subsequent decades had experiences of antisemitic harassment and bullying particularly at non-Jewish schools and in the military. Martin, in his 60s, maintained that at his Pretoria boys' school 'it was just completely open, blatant antisemitism all the time'. Among the examples he gave was the following story told by his science master:

M: He'd say, 'You know boys, Jews are known, very very wealthy people. Jews are very rich.' And he says, 'And you know that Jews have all got big noses.' So now of 
course by this time everybody in the class is turning round, pointing and laughing. And he says, 'These two facts are scientifically linked. And they are linked through the fact that Jews, because they’ve got big noses, can get more oxygen into their brains, so they can make more money. [...] I just took that as, well that was the norm, you know, that's what happened. I didn't realise how outrageous that was. ${ }^{25}$

Richard, also in his 60s, recalled a 'huge amount' of antisemitic bullying at his Johannesburg high school. ${ }^{26}$ Both men further reported experiencing 'vicious' antisemitism during their time in the armed forces. Richard remembered 'comments all the time, they were just always disparaging. [...] "You fucking Jood [Jew]." I mean it was just like all the time, continuous, continuous, continuous, continuous. ${ }^{27}$ Five respondents in their 50 s and 60 s reported similar experiences, although alongside these accounts, fourteen respondents in similar age categories stated that they had experienced little or no antisemitism growing up in South Africa. Those from Johannesburg generally reported less discrimination than those in smaller centres, although even in the latter antisemitism was not always evident.

Experiences and perceptions are of course two different things, and memory leaves powerful residues even when reality is substantially changed. Earlier studies of South African Jews confirmed that diverging experiences such as those recounted by our respondentsfierce antisemitism as well as its near-absence-were common. In pointing to the lack of antisemitism in South Africa, Paul and other younger respondents found it easier to conclude that because Jews did not experience victimhood in the here and now, their sense of victimhood was disingenuous. Others - particularly those who were temporally closer to earlier histories of antisemitism, whether or not they had experienced antisemitism themselves - expressed a sense of vulnerability that complicated the way in which they 
related to the position of the perceived mainstream. Even though they were uneasy about some of its attitudes, they could still identify with some of its fears.

For our respondents, memory of Jewish persecution and especially the Holocaust bore implications for two distinct issues: racism in South Africa, and Israel's conflict with the Palestinians. Many identified strongly with the imperative to promote social justice and combat racism, a mission some associated directly with the Holocaust and (sometimes rather vague) ideas of 'Jewish values'. Les, in his 70 s, for example, recounted the atmosphere among his friends in the 1960s and 70s:

This was not long after the Holocaust and there was still that very strong feeling that the shadow of the Holocaust was still over us and that had certain moral obligations that came with it. To make sure that something like that didn't happen again, and then there was apartheid and it was equated in some way with what had happened to the Jews. $^{28}$

At the time, such responses hardly featured in mainstream narratives, which, as indicated earlier, centred largely on Israel and made few links with the local context. From the 1960s, the universal 'lessons' of Jewish history and ethics were more likely confined to those, like Les and his progressive circle, who identified resonances between Jewish historical experience and present struggles in South Africa. Since the end of apartheid, by contrast, public narratives of Holocaust memory in South Africa have embraced many of the same universal themes that dominate remembrance globally. Within the Jewish mainstream, however, there remains a deep unease about pushing the connections between the Holocaust and other genocides or human rights abuses too far. ${ }^{29}$ 
These divided memory cultures resonated clearly in the words of Les and some of our other respondents. While many root their attitudes in memory of the Holocaust, the 'lessons' they draw are aligned more closely with those peripheral Jews who actively embraced antiracism during the apartheid years than they are with the more prominent and powerful voices of local Jewry. Warren, for example, in his 30 s, referred explicitly to this legacy when he explained his strong identification with

one version of the white South African Jewish narrative [which] is the family story of the Holocaust $[\ldots]$, internalising a strong sense of the pain and the trauma of the Holocaust, and then looking around and seeing what's happening, usually through parents who are doing that. And then feeling impelled as a Jew, in the name of that past, to become involved in some or other way. ${ }^{30}$

In our interviews, respondents across the range of ages insisted in similar ways on linking historic Jewish victimhood with a present commitment to anti-racism and social justice.

The second key impact of the Holocaust on our respondents' identities was the strong sense of potential Jewish vulnerability it underpinned, which translated for some into the deeply-felt necessity of the Jewish homeland. Reconciling these emotional connections to Israel with their intense discomfort with the country's politics, as well as mainstream Jewry's unquestioning support, was for many an intensely vexed issue. Richard, in his 60s, explained his position thus:

I think that Jews have been persecuted throughout history, and as such, I think that they have the right to claim something for themselves. [...] I know that people keep saying, 'The Jews are just, everything comes back to the Holocaust and it gives them 
the justification to claim what others can't.' [...] You lose six million people, give or take a few hundred thousand, I think it gives you certain rights to an identity. [...] In the context of the Middle East, people will do a hell of a lot to justify whatever they want to do. But do I believe in a Jewish state? Yes, I believe in a Jewish state. I think they've earned their stripes, in a horrible way.

While making clear that the Holocaust should not be used to excuse unjust behaviour, particularly in the Middle East, Richard also believed that the persecution of Jews 'throughout history' gave them the right to a state of their own. His allusion to the IsraeliPalestinian conflict was addressed more directly by Gina, in her 30s:

I acknowledge the Nakba, but I also wonder like, where were people meant to go? Because it's very easy to look in hindsight and say, Jews could have stayed in Europe. [...] But they couldn't, and I've really tried to read about the circumstances that Jews were living in, post-World War Two Europe, and they really couldn't stay there. [...] Nowadays it's easy to say that [Israel's] founding was wrong, in a sense, but that doesn't really answer the... at the time, what the world was meant to do with this massive, floating Jewish population that no one actually really wanted.

The necessity of Israel as a haven from persecution is of course a point regularly stressed by the country's less critical defenders. This was not lost on our respondents, who took pains to differentiate their positions from what they perceived to be the dominant refusal to acknowledge Palestinian suffering, and what they saw as a deliberate mobilization of the Holocaust to justify unquestioning support for Israel. A few took their censure further, identifying a common thread of racism that linked the mainstream outlook on Israel and 
South Africa. Evan, in his 40s, for example, maintained that 'there's a feeling of superiority over Arab people that people don't want to admit is [...] very similar to white people's feeling of superiority over black people in South Africa.' Like those cited above, however, his criticism of Israel coexisted with an intense identification with historic Jewish victimhood and a deep-seated, if highly ambivalent, appreciation of the need for a Jewish state.

When respondents rejected the centrality of the Holocaust to their Jewish identities, then, they were not rejecting the significance of the Holocaust itself; rather, they were objecting to what they considered an undue emphasis on victimhood in order to justify attitudes they considered unacceptable. Almost all of our respondents, regardless of age, were critical of the policies of the current Israeli government and the reflexively supportive positions taken by South African Jewry. While many nonetheless felt connected to Israel, as we have seen, those in their 20 s and 30s in particular criticized what they perceived to be the use of an exaggerated fear of Jewish victimhood to justify uncritical support for the state. Alongside his fear that the absence of Israel would result in "genocide," for example, Alon, in his 20 s, expressed frustration that "at school people used to invoke the Holocaust for political ends. Were always doing so in the Israel context and saying, 'Well Israel justifies what it's doing because of the Holocaust'", ${ }^{31}$ Dylan, also in his 20 s, read the situation thus:

The first generation has the pain of the Holocaust. And has the pain of persecution. Second generation has inherited pain, that generational sense of pain. So antisemitism's still real. But I mean especially now with Israel narratives, if you talk about the [South African] Zionist Federation, you have to actively breed this impression that everybody hates us, and everybody hates Israel, and you have to buy into that and share it. ${ }^{32}$ 
Others echoed these sentiments, claiming that communal narratives portrayed Israel's victories with no reference to the Palestinians, and justified their position through a narrative of victimhood. We have discussed our findings in this area more extensively elsewhere. ${ }^{33}$

Respondents also associated the dominant focus on Jewish victimhood with increasing insularity and withdrawal from wider South African society. In particular, they criticized what they perceived to be racist attitudes toward non-whites both during and after apartheid. Several respondents who lived under apartheid asserted that racism had been common among Jews, and that it was hardly an issue for discussion or concern. Natalie, in her 40s, recalled that in her orthodox Jewish school,

everybody called blacks 'shvartsers.' And they used to think I was liberal, like I was the liberal girl in the school, and they thought it was so quaint. But no one else was like that, it wasn't anything to be ashamed of that [...] you didn't really like black people. $^{34}$

Brenda, in her $60 \mathrm{~s}$, marvelled at her relatives' ability to express racist attitudes without recognizing the irony of Jews taking such a position:

I remember saying to my grandfather, 'How can you have these attitudes, when Jews have experienced this kind of...' I wouldn't have had the word racism, but I couldn't understand why he could have racist attitudes when the Jews had been at the receiving end of racist attitudes. And I remember asking him about it, and I remember what he said to me, he said, 'Ach, you know,' - I don't even like to repeat it - 'These shvartzsers, you know, if I could pull myself by my own bootstraps, so can they. Why 
haven't they done that?' So, I mean I don't think he really understood structural inequality.

During apartheid, the dearth of Jewish opposition to the regime was often ascribed to fears for Jewish safety, given the history of Afrikaner antisemitism and the context of a police state. For some of our respondents, however, the insistence on victimhood was a disingenuous defence for the refusal to speak out against apartheid before the mid-1980s. ${ }^{35}$

Younger respondents talked about the post-apartheid period in similar ways. Hannah, in her 20s, noted that in her Johannesburg school, Holocaust history 'was often portrayed like $[\ldots]$ this happened once and it could happen again. Everyone still hates us, we've got to stick together, you've got to hold on to tradition, don't assimilate. ${ }^{36}$ In her view, which was echoed by others, the emphasis on Jewish victimhood was mobilized to encourage increased communal engagement and religious observance. Adam, in his 20s, shared this view of mainstream Jewry's insularity, associating it more explicitly with what he saw as a failure to engage with South African 'others':

I do feel that like one of my many problems with the idea of Judaism at [my Jewish school in Cape Town] was this idea of security. And antisemitism was a massive narrative. Huge, huge, huge. It's part of how they keep the bubble alive. Is this idea that other people are not going to accept you. Antisemitism is rife in the world, people don't like you. So that's scary and that makes you want to stick where you feel safe and not venture out. That's why there's like mountains of CSO [Community Security Organisation] on a school trip, you know, you're going nowhere in particular, you're just a bunch of schoolkids and then people act as if there's going to be a terrorist attack. And I feel like that narrative was very unhealthy [...] for allowing people the 
chance to venture out and experience friendships with people who are not exactly like themselves.

The focus on victimhood, in Adam's view, allowed his school to justify a position of separateness and disengagement from the diversity of contemporary South Africa. Some also claimed that it prevented Jews from confronting their collective position and responses during apartheid. Asher, in his 30s, said that at his Jewish school in Johannesburg,

You definitely learn that you're a victim. And the idea of reparations because you're white, feeling guilty because you're white, never entered. In fact it was often, 'Look what the Jews did during apartheid, they're so great. Well done.' But despite coming from the Holocaust background they still fought for apartheid. We never learnt about the Jews who were selling skin whitening products. ${ }^{37}$

Other respondents articulated their unease in similar terms, claiming that the preoccupation with victimhood allowed Jews to avoid grappling with questions about how they might have benefited from apartheid or even been complicit in its injustices.

Paradoxically, while the younger Jews we spoke to rejected the notion that victimhood was central to their Jewish identities, their position in contemporary South Africa is in some ways more precarious than that of their parents' and grandparents' generations. This is not so much because of their Jewishness as because of their whiteness. The legacy of apartheid has posed profound challenges for white identity in general, a phenomenon that is being documented in a growing literature. ${ }^{38}$ Several of our respondents felt that their whiteness was a barrier to full entry into South African society, and prevented them from participating in conversations about the country's present and future. While some older respondents wrestled 
with similar anxieties, young people seem to experience them particularly acutely as they work to forge adult lives and careers.

At the same time, they felt there was little room for them in a Jewish context in which identity is defined in largely negative rather than positive terms. Steve, in his 40 s, insisted that 'historical wrongs don't define me. My Jewish identity, whilst it recognises and deals with the history, builds on it and moves forward.' Jacob, in his early $30 \mathrm{~s}$, similarly expressed concern that South African Jewry’s identity was grounded primarily in the memory of antisemitism and the Holocaust:

It's a very negative identity. I don't think there's very much to build on. [...] No-one can articulate what's worth saving beyond the fact that people are trying to destroy it and therefore we have to save it. [...The Jewish community] doesn't really have a strong social justice element and it doesn't really have a strong Jewish textual or intellectual connection or religious connection. It's just a memory. And I see that as very dangerous. ${ }^{39}$

In Jacob's view, the lack of Jewish substance is leading to some of the brightest young Jews pursuing their political and social activism outside the Jewish sphere, where their progressive ideals find a more natural home despite the attendant challenges.

Perspectives such as Jacob's, and those of our other respondents, are doubtless in the minority. For most South African Jews, the organised community provides a safe and reassuring framework for Jewish life. The concerns that they articulated in our interviews nonetheless resonate with developments over the past decade or so elsewhere in the Diaspora, which have drawn increasing scholarly as well as communal attention. 


\section{Conclusion}

Writing about American Jewry, the journalist Peter Beinart maintains that the persistent narrative of historic victimhood is fomenting a 'crisis' by reinforcing a negative Jewish identity and justifying unquestioning support for the Israeli state. 'We need a new American Jewish story,' he writes, 'built around this basic truth: We are not history's permanent victims. ${ }^{40}$ Beinart focuses especially on attitudes toward Israel and the conflict with the Palestinians, and his views have resonated with progressive Jews who are increasingly uncomfortable with the idea that 'Jews are licensed by their victimhood to worry only about themselves'. ${ }^{41}$

In South Africa, comparable trends are evident, even if the numbers are smaller than elsewhere. ${ }^{42}$ In refusing victim-centred narratives, progressive Jews such as those we spoke to are similarly objecting to a negative definition of Jewish identity and to what they see as mainstream Jewry's reflexively supportive position on Israel. But in the post-apartheid context there are additional, distinctively South African inflections. For our respondents, the dominant focus on historic Jewish victimhood — whether with reference to Afrikaner antisemitism or the longer history of Jewish suffering in Europe- has justified a reluctance to acknowledge the victimhood of others, and they are uncomfortable with what they consider to be an unjustifiably inward-looking stance. While the history of Jewish persecution significantly informed their understanding of their Jewishness, particularly in the South African context, they took pains to distance their position from that of the mainstream, which in their view emphasizes the particular implications of the Holocaust at the expense of the universal. In doing this, they echoed the diverging Holocaust memory cultures that developed during the apartheid years.

While respondents across the range of ages were clear in their rejection of communal narratives, there were generational differences in their approach to the question of Jewish 
victimhood. Among older respondents, the relationship to victimhood was more ambivalent and emotive than it was for younger respondents. The former grew up in closer temporal proximity to their parents' and grandparents' experiences of antisemitism in Europe as well as in South Africa in the 1930s and 40s, and some had also had their own significant encounters at non-Jewish schools and in the military. To be sure, antisemitism during the apartheid period did not threaten Jews' security or life chances in the same way that racism threatened that of non-whites, as some respondents acknowledged. These encounters were nonetheless unpleasant and frightening, and clearly impacted on Jews' enduring sense of potential vulnerability, particularly against the backdrop of the long Jewish history of persecution. For younger respondents, by contrast, the question of their whiteness poses far more of an issue post-apartheid than their Jewishness. They are not impervious to contemporary threats of antisemitism, and many feel strongly the need for a Jewish state, but they do not accept the centrality of victimhood to their Jewish identities. Whether they are able to find productive alternative forums within which to develop their Jewishness in contemporary South Africa, as progressive Jews elsewhere in the Diaspora are beginning to do, remains to be seen.

\footnotetext{
${ }^{1}$ The sample comprised a mix of genders and generation, with 13 in their 20 s, 16 in their $30 \mathrm{~s}$ and 40s, and 26 over the age of 50. There were 28 women and 27 men. Almost all of the respondents in their 20s were university students or recent graduates. Respondents were identified either on the basis of their participation in progressive Jewish fora in South Africa, notably Limmud (in the manner of purposive sampling), or were suggested by existing respondents (snowball sampling). All the interviews were in-depth and semi-structured, typically around two hours in length. We have used pseudonyms in the article in order to maintain the respondents' anonymity.
} 
2 Judy Maltz. 2019. “Jews Are Leaving South Africa Once Again — but Don't Blame BDS."

Ha' ${ }^{\prime}$ retz, 16 June. https://www.haaretz.com/world-news/asia-and-australia/.premium-jews$\underline{\text { are-leaving-south-africa-once-again-but-don-t-blame-bds-1.7366376 }}$

${ }^{3}$ Furlong, Patrick J. Between Crown and Swastika: The Impact of the Radical Right on the Afrikaner Nationalist Movement in the Fascist Era. Middletown, CT: Wesleyan University Press, 1991, 20, 16, 83, 138-143, 161-2; Shimoni, Gideon. Community and Conscience: The Jews in Apartheid South Africa. Hanover, N.H: Brandeis University Press, 2003, 11-16; Christoph Marx, Oxwagon Sentinel. Radical Afrikaner Nationalism and the History of the Ossewabrandwag (Pretoria: Unisa Press, 2008); Richard Mendelsohn and Milton Shain, The Jews in South Africa: An Illustrated History (Johannesburg and Cape Town: Jonathan Ball, 2008), 106-11; Shain, Milton. A Perfect Storm: Antisemitism in South Africa, 1930-1948. Johannesburg and Cape Town: Jonathan Ball, 2015.

${ }^{4}$ Gitlin, Marcia. The Vision Amazing: The Story of South African Zionism. Johannesburg: Menorah Book Club, 1950; Shimoni, Gideon. Jews and Zionism: The South African Experience (1910-1967). Cape Town: Oxford University Press, 1980; Mendelsohn and Shain, The Jews in South Africa, 190-1.

${ }^{5}$ Dellapergola, Sergio, and Allie A Dubb. 'South African Jewry: A Sociodemographic Profile'. American Jewish Year Book 88 (1 January 1988): 59-142, here 102.

${ }^{6}$ Herman, Chaya. 'The Jewish Community in the Post-Apartheid Era: Same Narrative, Different Meaning'. Transformation: Critical Perspectives on Southern Africa 63 (2007): 23-44, here 38-9.

${ }^{7}$ Gilbert, Shirli. 'Jews and the Racial State: Legacies of the Holocaust in Apartheid South Africa, 1945-60'. Jewish Social Studies 16, no. 3 (2010): 32-64.

${ }^{8}$ See, for example, Suttner, Immanuel, ed. Cutting Through the Mountain: Interviews with South African Jewish Activists. Johannesburg: Viking Penguin, 1997. 
${ }^{9}$ See, for example, Report of the Executive Council of the South African Jewish Board of

Deputies, April 1958 to August 1960 (Johannesburg: South African Jewish Board of

Deputies, 1960), 33.

${ }^{10}$ Gilbert, 'Jews and the Racial State'.

${ }^{11}$ See, among others, Arkin, Marcus. South African Jewry: A Contemporary Survey. Cape Town: Oxford University Press, 1984; Dellapergola and Dubb. 'South African Jewry'; Dubb, Allie A. The Jewish Population of South Africa: The 1991 Sociodemographic Survey. Cape Town: Kaplan Centre for Jewish Studies and Research, University of Cape Town, 1994.

${ }^{12}$ Reports were published annually in the American Jewish Year Book under the categories (variously) 'Foreign Countries: Union of South Africa', 'Foreign Countries: Southern Africa' and 'Foreign Countries: South Africa'.

${ }^{13}$ See, for example, Bernstein, Edgar. 'Review of the Year (1955) in Foreign Countries: South Africa'. Edited by Morris Fine and Jacob Sloan. American Jewish Year Book 56 (January 1955): 457-65; Bernstein, Edgar, and Maurice Goldbloom. 'Review of the Year (1965) in Foreign Countries: Southern Africa'. American Jewish Year Book 66 (January 1966): 484-97; Diamond, Denis. 'Review of the Year (1979) in Foreign Countries: South Africa'. Edited by Milton Himmelfarb and Morris Fine. American Jewish Year Book 79 (January 1979): 283-90.

${ }^{14}$ Shain, Milton. 'South Africa'. In The World Reacts to the Holocaust, edited by David S Wyman. Baltimore: The Johns Hopkins University Press, 1996, 670-89, here 686-9.

${ }^{15}$ Kosmin, Barry A., Jacqueline Goldberg, Milton Shain, and Shirley Bruk. 'Jews of the "New South Africa": Highlights of the 1998 National Survey of South African Jews'. Institute for Jewish Policy Research, 1999; 2-3, 26.

http://www.jpr.org.uk/Reports/PJC_Reports/no 3 _1999/index.htm 
${ }^{16}$ Bruk, Shirley. 'The Jews of South Africa 2005: Report on a Research Study', 2005. http://www.kaplancentre.uct.ac.za/sites/default/files/image tool/images/151/Reports/Jews $\% 2$ 0of $\% 20$ SA $\% 202005 \% 20$ Report.pdf, 51-2.

${ }^{17}$ Bruk, 'The Jews of South Africa', 53; Shain, Milton. 'South African Jewry: A Glimpse Into the Future'. Sh'ma: A Journal of Jewish Ideas, 1 November 2003, 5-6; Shain, Milton, and Margo Bastos. 'Muslim Antisemitism and Anti-Zionism in South Africa since 1945'. Antisemitism International 3-4 (2006): 18-30.

${ }^{18}$ See, for example, David Saks. 2014. 'Tolerance for differing views on Israel Gaza goes both ways.' Sunday Times, 24 August.

${ }^{19}$ Gilbert, Shirli. 'Remembering the Racial State: Holocaust Memory in Post-Apartheid South Africa'. In Holocaust Memory in a Globalizing World, edited by Jacob S. Eder, Philipp Gassert, and Jacob S. Steinweis, Alan E. Göttingen: Wallstein, 2017, 199-214; Gilbert, Shirli. 'Anne Frank in South Africa: Remembering the Holocaust During and After Apartheid'. Holocaust and Genocide Studies 26, no. 3 (2012): 366-93; Gilbert, Shirli. 'Nazism and Racism in South African Textbooks'. In Holocaust Memory and Racism in the Postwar World, edited by Shirli Gilbert and Avril Alba. Detroit: Wayne State University Press, 2019, 350-85.

${ }^{20}$ Interview with Paul.

${ }^{21}$ Interview with Dylan.

${ }^{22}$ Interview with Jacob.

${ }^{23}$ Interview with Judy.

${ }^{24}$ Interview with Renée.

${ }^{25}$ Interview with Martin.

${ }^{26}$ Interview with Richard.

${ }^{27}$ Interview with Richard. 
${ }^{28}$ Interview with Les.

${ }^{29}$ Gilbert, 'Remembering the Racial State'.

${ }^{30}$ Interview with Warren.

${ }^{31}$ Interview with Alon.

${ }^{32}$ Interview with Dylan.

${ }^{33}$ Gilbert, Shirli and Deborah Posel, 'Israel, Apartheid, and a South African Jewish

Dilemma'. Journal of Modern Jewish Studies (forthcoming).

${ }^{34}$ Interview with Natalie.

${ }^{35}$ For a useful overview, see the introduction to Braude, Claudia Bathsheba, ed.

Contemporary Jewish Writing in South Africa: An Anthology.

${ }^{36}$ Interview with Hannah.

${ }^{37}$ Interview with Asher.

${ }^{38}$ See, among others, Distiller, Natasha, and Melissa E. Steyn, eds. Under Construction:

'Race' and Identity in South Africa Today. Sandton: Heinemann, 2004; Steyn, Melissa, and

Don Foster. 'Repertoires for Talking White: Resistant Whiteness in Post-Apartheid South

Africa'. Ethnic and Racial Studies 31, no. 1 (1 January 2008): 25-51.

${ }^{39}$ Interview with Jacob.

${ }^{40}$ Beinart, Peter. The Crisis of Zionism. New York, N.Y: Picador, 2013, p. 8.

${ }^{41}$ Beinart, Peter. 'The Failure of the American Jewish Establishment'. New York Review of Books, no. 10 June (2010).

${ }^{42}$ Bloom, Kevin. 'Who Will Shake SA Jewry's Faith in Israel?' Mail and Guardian, 7 May 2012. 